\title{
Clarifications, guidelines and questions about the dental bleaching "associated" with orthodontic treatment
}

\author{
Alberto Consolaroํ, Renata Bianco Consolaro², Leda Francischone ${ }^{3}$
}

\begin{abstract}
With regard to the best moment for carrying out or recommending dental bleaching to orthodontic patients, some explanations and orientations are given in order to answers the following questions: 1) Why orthodontic treatment completion is considered the best opportunity for carrying out the procedure? 2) Why dental bleaching should not be performed immediately before orthodontic treatment? 3) If that would be possible at any special case, what would that be? 4) Why dental bleaching should not be performed during orthodontic treatment? 5) If that would be possible at any special case, what would that be? This article highlights why it is essential to protect both the mucosa and the cervical region, regardless of the moment when dental bleaching is performed, whether associated with orthodontic treatment or not. The "how", "why" and "if" of whether or not it is convenient to perform dental bleaching before orthodontic treatment are still a matter of clinical suggestion, as it is a procedure that is under analysis, empirical knowledge waiting for scientific proof or disproof? Although tooth enamel has adamantine fluid flowing within it, providing a specific metabolism that is peculiar to its own and which could scientifically explain and base the option of carrying out teeth whitening before and during orthodontic treatment, we must still be very careful.
\end{abstract}

Keywords: Teeth whitening. Dental bleaching. Orthodontic treatment.

Quanto ao melhor momento para se aplicar ou recomendar a clareação dentária aos pacientes ortodônticos, alguns esclarecimentos e orientações são explanados para responder questionamentos como: 1) Por que depois do tratamento ortodôntico se constitui a melhor oportunidade para tal procedimento?; 2) Por que não realizar a clareação dentária imediatamente antes do tratamento ortodôntico?; 3) Se poderia realizá-la em alguma condição especial, e qual seria?; 4) Por que não se deveria clarear os dentes durante o tratamento ortodôntico?; 5) Se possível em algumas situações especiais, quando seriam essas situações especiais? No presente artigo, se destacará porque é fundamental sempre proteger a mucosa e a região cervical, independentemente do momento em que se fizer uma clareação dentária relacionada ou não ao tratamento ortodôntico. O mecanismo de como, por que e se é ou não conveniente clarear os dentes antes da finalização dos tratamentos ortodônticos ainda representa uma sugestão clínica, um procedimento em análise e um conhecimento empírico à espera de sua comprovação ou desmitificação científica. Apesar do esmalte dentário ter uma circulação do líquido adamantino, que propicia um metabolismo próprio e específico, que pode vir a ser, cientificamente, a base para explicar e fundamentar a clareação dentária antes e durante o tratamento ortodôntico, ainda assim devemos ser muito cautelosos.

Palavras-chave: Clareação dentária. Clareamento dentário. Tratamento ortodôntico.

There was a time, before the 80 s, when the orthodontist would perform tooth movement as well as malocclusion and esthetic correction only in young patients with all teeth, without prosthesis or implants, with completely healthy teeth and gingiva.

In addition to responding to functional and esthetic needs of patients of all ages and with different oral and systemic health conditions, the orthodontist has cur-

${ }^{1}$ Head Professor, FOB-USP. Professor of the Post-Graduation Course, FORPUSP.

${ }^{2}$ Professor, Adamantinenses Integrated Schools (FAI). PhD in Pathology, FOB-USP.

${ }^{3} \mathrm{PhD}$ in Oral Pathology, College of Dentistry - Bauru/USP.

" The authors report no commercial, proprietary or financial interest in the products or companies described in this article. rently supported and helped with other types of oral rehabilitation treatments which vary in complexity.

During orthodontic planning, even before treatment onset, when patient's expectations and projections are still being surveyed, patients tend to question the clinician about when and how is the best moment for dental bleaching. White healthy teeth are an individual as well as a social need.

How to cite this article: Consolaro A, Consolaro RB, Francischone L. Clarifications, guidelines and questions about the dental bleaching "associated" with orthodontic treatment. Dental Press J Orthod. 2013 Sept-Oct;18(5):4-10.

Submitted: July 04, 2013

Revised and accepted: July 10, 2013

Contact address: Alberto Consolaro

E-mail: consolaro@uol.com.br 
Generally, in clinical practice, dental bleaching must be performed prior to restorative and rehabilitative treatments, since such procedures are carried out on the basis of the color obtained from the bleaching technique. Teeth and lost spaces will be restored in harmony with all components of the future smile.

In Orthodontics, however, dental bleaching must be performed after the orthodontic appliance has been removed, except for specific cases with particular purposes.

Based on orthodontic treatment patterns, this article discusses the precautions, explanations and orientations related to the best moment for carrying out dental bleaching, as described in a previously published article 9 .

After such discussion, we will explain about the basis on which companies and clinicians have recommended or indicated dental bleaching for patients undergoing orthodontic treatment.

\section{WHY DENTAL BLEACHING SHOULD BE PER- FORMED AFTER ORTHODONTIC TREATMENT?}

After orthodontic treatment finishes, all crown surfaces are positioned, properly exposed and ready to uniformly receive the bleaching agent. Nevertheless, the initial results will not necessarily be uniform as some teeth may require additional application. This is due to the fact that not all teeth have the same color, just like the whole dental structure, especially the enamel, does not have the same volume, thickness and level of mineralization for all its elements.

In some cases, after the orthodontic appliance has been removed, the surfaces below the brackets may be irregular with regard to surface and color, and have resin fragments adhered to the enamel. These surfaces need to be evened with restorative abrasive procedures or remineralized in order to have uniform color and surface.

Moreover, after orthodontic appliances have been removed, some adjustments must be made to the oral environment. Focal and occasional gingivitis must be reversed and the dental plaque properly controlled. After two to four weeks, these adjustments may lead to an oral environment that is ideal for a more efficient and uniform dental bleaching. Dental plaque, calculus and resin fragments hinder the action of the bleaching agent on the enamel surface. Gingivitis weakens the gingiva in cases in which the bleaching agent accidently reaches its structure.

\section{WHY DENTAL BLEACHING SHOULD NOT BE PERFORMED BEFORE ORTHODONTIC TREAT- MENT? OR IT SHOULD? WHEN?}

In orthodontic treatment, teeth may be intruded or extruded, exposing areas previously covered by gingiva in case of malpositioned or unerupted teeth, a common situation for the maxillary canines. Should the procedure be carried out before orthodontic treatment, the areas covered by gingiva or touching other teeth will not receive the bleaching agent as the other areas will. Such areas are exposed after orthodontic treatment and may end up having a different color.

Bleaching agents are hydrogen peroxide-based acid solutions that act over the teeth. ${ }^{2,6}$ They act over the enamel surface causing it to be more porous. Simultaneously or soon after bracket placement, an acid attack is required in order to allow the resin to adhere to the enamel when it is being placed on the dental crown, in which case the enamel below these surfaces may be structurally weakened. When brackets are removed, enamel splinters may be detached, harming its surface.

Resin restorations may present increased infiltrations due to the hydrogen peroxide demineralization action and infiltrating capacity. Thus, it would not be different between resin and bracket on the enamel surface, causing it to easily detach. Similarly, dental plaque bacterial acids tend to accumulate and remain active, causing white spot lesions underneath the brackets, especially if the patient is not careful with his own oral hygiene.

Exposed crown area, where the enamel is more porous, is more subject to stronger dental plaques due to greater mechanical retention caused by brackets and other orthodontic devices.

But, is it possible? When? The appearance of teeth may be generally improved at the first sessions of dental bleaching due to the cleaning efficacy of hydrogen peroxide which penetrates into the smallest recesses such as lamellas, splits or natural depressions and irregularities of the enamel. The pigments in these irregularities will be promptly removed at the first sessions of dental bleaching. 
Such an improvement may be motivating for the patient to withstand a long orthodontic treatment. However, it is worth noting that, for this purpose, the bleaching procedure must be brief and with a very specific aim. In addition, its application must be well controlled by a qualified professional.

Another reason for having dental bleaching performed before orthodontic treatment may be of professional nature, especially if we consider that the appearance often predominates over candidates' theoretical or philosophical content. In the case of photographic models and other professionals who depend on their image and exposure, white clean teeth are required. The same happens when the patient attends job interviews or other selection processes related to job or artistic opportunities.

\section{WHY DENTAL BLEACHING SHOULD NOT BE PERFORMED DURING ORTHODONTIC TREATMENT? OR IT SHOULD? WHEN?}

Pores and perikymata exposure on the enamel surface will not happen in a controlled and uniform way in the areas below the brackets, even if infiltration between the fixing resin and the dental crown is possible. Moreover, no studies have been carried out to investigate how the enamel and its respective structures as well as the physiology of areas below the fixed brackets act when subjected to bleaching agents.

The areas covered by gingiva or touching other teeth will not receive the bleaching agent as the other areas will. The risk of stains and irregularities in color and surface after brackets removal is high, and the costbenefit relationship is not worthy in normal cases.

Resin restorations may increase infiltrations by hydrogen peroxide demineralization action and infiltrating capacity. Thus, it would not be different between resin and bracket on the enamel surface, causing it to easily detach. Dental plaque bacterial acids tend to accumulate and remain active, causing white-spot lesions underneath the brackets, especially if the patient is not careful with his own oral hygiene. Exposed crown area, where the enamel is more porous, is more subject to stronger dental plaques due to greater mechanical retention caused by brackets and other orthodontic devices.

But, is it possible? When? In specific cases, it may be necessary to improve the appearance of pigmented irregularities between the brackets, teeth and appliances, because since the first sessions of dental bleaching, the appearance of teeth may be generally improved due to the cleaning efficacy of hydrogen peroxide which penetrates into the smallest recesses such as lamellas, cracks or natural depressions and irregularities of the enamel.

A cleaner aspect of the orthodontic appliance may be a motivating factor for the patient to withstand a long orthodontic treatment. However, it is worth noting that, for this purpose, the bleaching procedure must be brief and with a very specific aim. When the purpose is to effectively bleach teeth with fixed brackets, it should be highlighted that the risk of stains and irregularities in color and surface after bracket removal is high.

Additionally, the bleached enamel may be weaker in structure. In normal cases, surface enamel is eventually removed when brackets are removed. However, it is unknown whether or not this situation increases in cases of bleached enamel.

Another reason for having dental bleaching performed during or before orthodontic treatment may be of professional nature, especially if we consider that appearance often predominates over candidates' intellectual and emotional content.

In the case of photographic models and other professionals who depend on their image and exposure, white clean teeth are required. The same happens when the patient attends job interviews or other selection processes related to job or artistic opportunities. The use of appliances alone may not affect the aspect employers expect from candidates, however, should they have healthy teeth, without dental plaque or pigmentation that give them an unpleasant appearance at smiling, they will not be restrained from being hired.

\section{MUCOSA AND CERVICAL REGION PROTECTION: ALWAYS, REGARDLESS OF THE MOMENT!}

Dental bleaching requires qualified professionals who are capable of performing the procedure on the patient. Protection of the oral mucosa and the cervical region of teeth is among the abilities the professional must have. ${ }^{1,2,4,5-8}$ The cervical enamel is thin, with beveled thickness which irregularly and 
structurally relates itself to the cementum that covers the root. Along the cementoenamel junction, all permanent or deciduous teeth exhibit areas or gaps with dentin exposed to the oral environment. ${ }^{4-7}$

Exposure of dentin windows to the oral environment occurs when the cementoenamel junction "migrates" or is displaced from the gingival connective tissue to the groove due to migration or continuous and compensatory dental eruption mechanism of abrasion in the incisal edges and occlusal aspects.

When exposed to bleaching agents, the areas of dentin exposure and the dental tubules are widened. $\underline{6}$ These effects result in excessive and uncomfortable increase in dental sensibility after bleaching, which may result in unbearable discomfort for a few patients. Thus, protecting the cervical region which receives the bleaching agent during the procedure is essential. From a clinical point of view, the most efficient and practical form to do so is by means of resin protective cervical barriers, ${ }^{4}$ however, other options may be used to protect the cervical region. Rubber sheets, for instance, which are used in restorative procedures and not widely used nowadays.

In addition to protecting the cementoenamel junction, the resin protective cervical barrier also protects the gingival mucosa against hydrogen peroxide-based bleaching agents. ${ }^{2,4}$ Many researches reveal that hydrogen peroxide may promote chemical carcinogenesis of mucosa, including the oral mucosa. ${ }^{1,8}$ Promoters of chemical carcinogenesis are those products that maximize the mutagenic effect of other agents and for this reason are considered carcinogenesis initiators. They are largely present in the mouth in the form of tobacco, herbicide, pesticide, alcohol, virus and many other substances. ${ }^{1,8}$

The resin cervical barrier protects the oral mucosa from receiving hydrogen peroxide provided that before it is removed, the dentist uses a specific type of suction tube to suck the gel or bleaching substance. It is advisable to cut the outer part of the disposable tip so that it becomes more efficient to suck the smallest portions of hydrogen peroxide present in the small recesses between the resin barrier and the tooth. ${ }^{4}$

The suction tube, or its disposable active part, that sucks saliva cannot be the same one that removes the bleaching agent as it will be contaminated by hydro- gen peroxide and, thus, contaminate the oral mucosa. If the tube is not carefully used, there is no point in using the resin cervical barrier, which must be taken off only after all hydrogen peroxide has been removed. Should there be hydrogen peroxide left in the patient's mouth, he will swallow it and the substance will affect his gastrointestinal mucosa with the same potential carcinogenic effects.

\section{HOW CAN WE UNDERSTAND THAT BLEACH- ING AGENTS POSSIBLY ACT ON THE ENAMEL SURFACE BELOW THE BRACKETS?}

Some standard procedures are based on clinical observation that is, in general, a result of a venturesome procedure carried out on the basis of previous clinical processes employed in similar cases, aiming at broadening the horizons of clinical practice. After knowing about these "indications and results", researchers and scholars analyze the biological applicability and feasibility of procedures. How can we explain about the basis on which companies and clinicians have "recommended" or "indicated" dental bleaching for patients undergoing orthodontic treatment?

First, we need to understand the enamel as a living tissue. Tooth enamel is alive, ${ }^{3}$ although it is commonly thought to be an inactive and amorphous tissue. Once the enamel is produced by the ameloblasts, it is formed by the rods, truly twisted and laterally connected beams. In cross section, the enamel rods are geometrically compared to a keyhole. Among the rods, there is an interrod sheath. Each rod is made up of millions of hexagonal crystals that may be compared to bricks or stones (Fig 1) among which the "adamantine fluid" flows.

In addition to taking part in the hydration process of each crystal, the adamantine fluid brings and takes ions from the enamel surface as well as from other parts of it. Due to the flow of adamantine fluid, the ions are incorporated into the enamel surface and may achieve its deepest parts, as it happens with the topic use of fluoride. This ion exchange allows enamel remineralization in the white spots caused by caries after external dental bleaching. At tooth eruption, the proportion of minerals between the deepest and surface enamel layers is similar, however, once it is exposed to the oral environment, the enamel surface becomes more mineralized and richer in fluoride. ${ }^{1}$ 
The wavy enamel surface, or perikymata surface, exhibits development pores (Fig 1), millions and true depressions that represent the marks left by the ameloblast Tomes' process when the last layer of ameloblasts is deposited. Fluids and ions enter through the surface pores, renewing the crystals. However, these pores also allow that other substances, including undesirable ones, enter the inner parts of the enamel.

When bacterial as well as other acids enter the enamel via pores and adamantine fluid, they promote demineralization of crystals, dissolving them as an ice cube melts inside a glass, reducing its structure and altering its form. The intercrystal space will increase in size, therefore, increasing enamel porosity, allowing even more undesirable agents, such as bacterial acids and pigments, to enter. Many of these products or agents may reach the dentin or even the dental pulp. At this stage, in enamel decay still in the form of white spots, there are subtle and subclinical localized pulp alterations. ${ }^{1}$

The enamel is alive! When leveling, cutting, removing, smoothing, bleaching and chemically changing the enamel, one aspect must be borne in mind: we are working with a living tissue. Similarly to the care given to the dentin, and even more, to the pulp, one must be careful when working with the enamel. ${ }^{1}$

When external dental bleaching is finished, the enamel surface pores are more open; resin bonding is weaker; orthodontic appliances are more prone to detaching; and the splits more open. Should acids be applied to the enamel for technical purposes, it must be done only if necessary. Demineralized enamel areas exposed to the oral environment are more prone to incorporating pigments and allowing toxic products and acids to enter, thus, promoting alterations in color and increased sensibility in the affected tooth.

Similarly, one must be selective and demanding when indicating or recommending cosmetic products, dentifrices, antiseptics, eating habits and special care related to the teeth, since these aspects influence enamel porosity, composition and structure as well as the dentin and the pulp. The flow of adamantine fluid among the enamel crystals connects the dental surface with the dentinal fluid. What we do to the enamel reflects on the dentin and, in smaller proportions, on the dental pulp. This is due to the fact that not only tooth color depends on the dentin, but also because there is a specific flow within these tissues. ${ }^{1}$

Women, who are careful about their jewels, wash them with seawater, handling, caring and keeping their pearls at special places because they strongly believe that the pearls are alive! They do not expose their pearls to perfume; neither allow them to rub against other surfaces. They want to prevent their pearls from dying and, as a consequence, losing their brightness, vigor and fascination. ${ }^{1}$

Hydrogen peroxide is highly penetrative in enamel; perhaps, it is the most penetrative chemical substance in dental structures. Should it be applied on enamel nearby, to which a bracket is adhered, hydrogen peroxide may reach the enamel subsurface and, thus, bleach the area of enamel that is covered by the bracket (Figs 1 and 2).

However, we must be careful, since we do not know how the hydrogen peroxide flows through the adamantine fluid: Does it flow uniformly? The bleached surface would become irregular, would it not? What is the speed of the bleaching agent diffusibility? Would hydrogen peroxide extend to lateral areas when applied on a surface? Wouldn't the bleaching procedures performed on enamel below the bracket weaken it and cause splinters to be broken off the enamel when brackets are removed?

Why are these questions in this article? This "Insight" sections aim at suggesting, highlighting and instigating new researches that prove or disprove theories, confirming hypothesis and producing scientific knowledge on the basis of concrete data and evidence! The "how", "why" and "if" of whether or not it is convenient to perform dental bleaching before orthodontic treatment are still a matter of clinical suggestion, as it is a procedure that is under analysis, empirical knowledge waiting for scientific proof or disproof?

\section{FINAL CONSIDERATIONS}

The best moment to recommend dental bleaching associated with orthodontic treatment coincides with treatment finishing because that is when all dental surfaces are uniformly exposed. What had to be extruded, intruded or leveled, had already been.

It may be considered an option, not a rule, in some special cases, in which situation the patient's lifestyle must be taken into account. Some precau- 

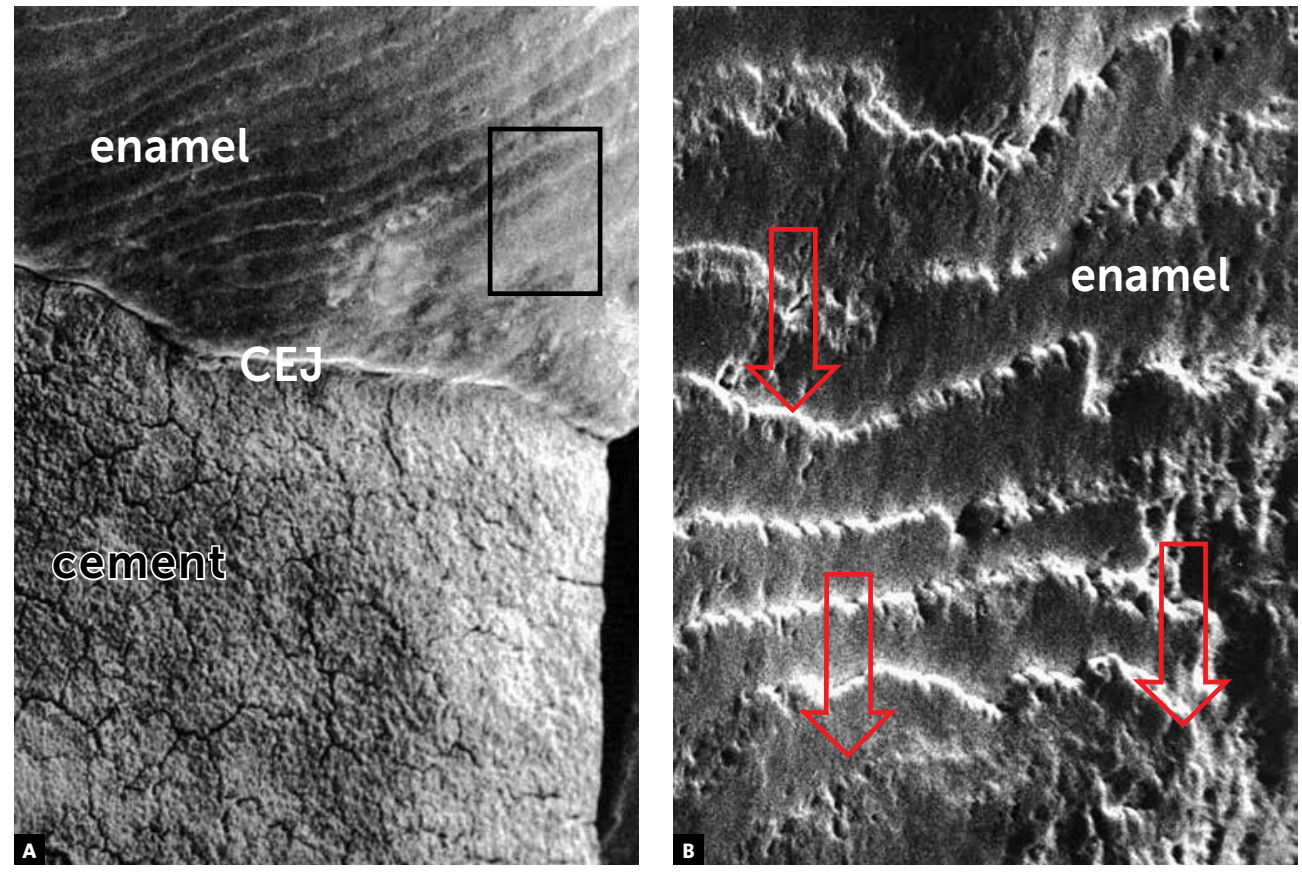

Figure 1 - Morphological aspects of human enamel surface in scanning electron microscopy: with perikymata, or wavy, and very porous. The cementoenamel junction (CEJ) is also observed. (SEM: 100x in A and $500 \mathrm{x}$ in $\mathrm{B}$ ).

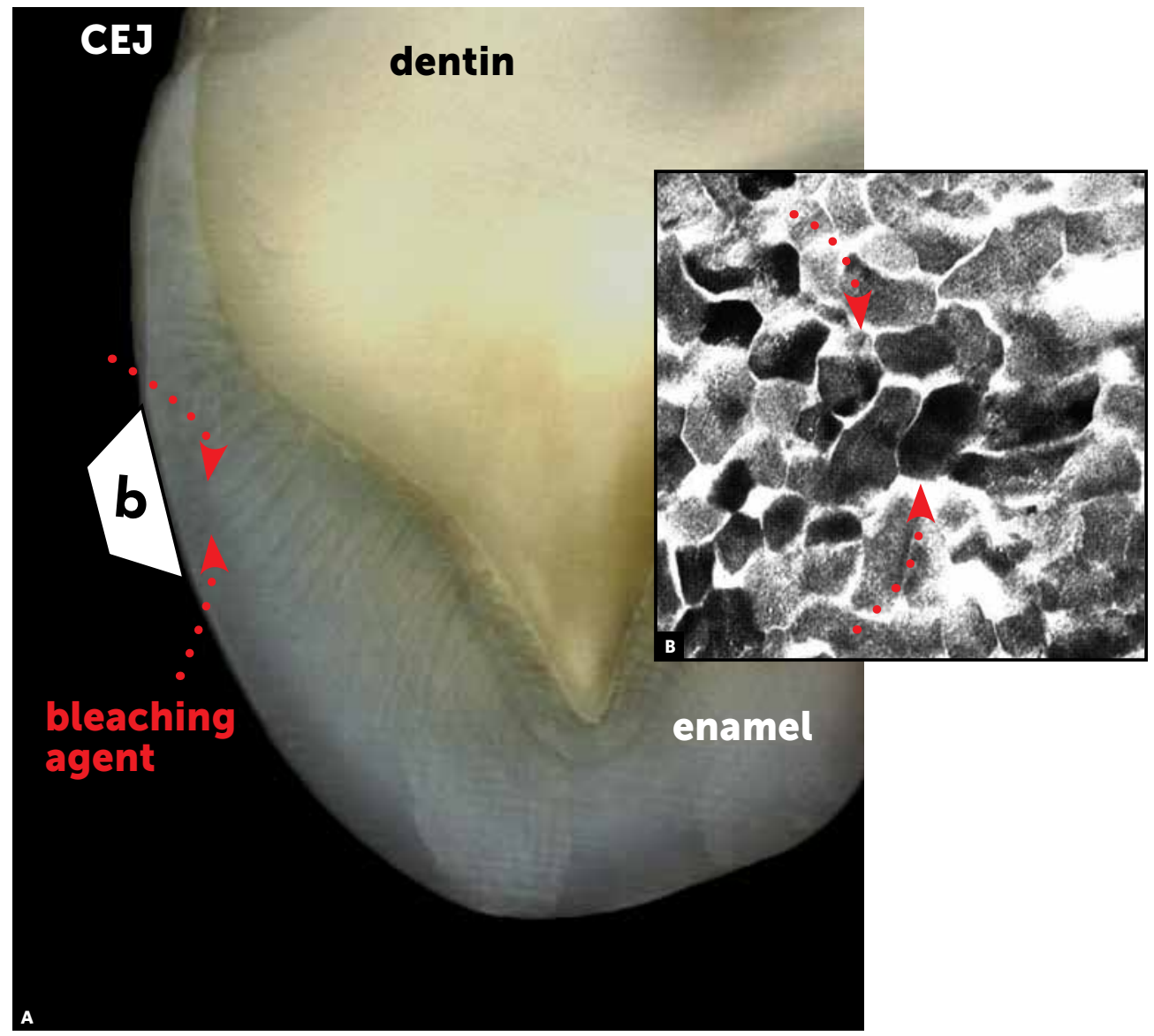

Figure 2 - A) Cross section of a human tooth. Morphological aspects of enamel surface and its relationship with the dentin and the cementum. (CEJ = cementoenamel junction). B) Transmission electron microscopy reveals the enamel crystals and the spaces where the adamantine fluid flows (arrows), which may carry the dental bleaching agent. 
tions and exceptions must be clarified when dental bleaching is exceptionally associated with orthodontic treatment before the latter is finished.

Frequent bracket detachment, white spots, loss of enamel color uniformity after orthodontic appliance is removed, retention of bacterial plaque and potential detachment of surface parts during brackets removal are among the consequences of dental bleaching associated with orthodontic treatment, due to the fact that bleaching agents promote enamel demineralization. Associating dental bleaching with orthodontic treatment is an exception that requires a lot of care and scientific knowledge. Additionally, it is of paramount importance that the patient knows about its potential risks.

It is worth noting that dental bleaching should always be performed by a qualified professional properly trained to act directly on the patient, always protecting the tooth cervical region as well as the oral mucosa with mechanical barriers - among which the resin barrier is the most widely used - in order to prevent the hydrogen peroxide from reaching the cementoenamel junction and its action on the oral mucosa.

The "how", "why" and "if" of whether or not it is convenient to perform dental bleaching before orthodontic treatment are still a matter of clinical suggestion, as it is a procedure that is under analysis, empirical knowledge waiting for scientific proof or disproof. Adamantine fluid flow in the dental enamel, with its own specific metabolism, may be the scientific basis to explain and justify the application of dental bleaching before and during orthodontic treatment. However, we must be very careful and wait for tests, results and evidences!
1. Camargo WR. Análise do potencial carcinogênico de dentifrício com peróxido de hidrogênio e de agente clareador dentário. Avaliações clínico-macroscópica e microscópica em hamsters em modelo de carcinogênese bucal DMBA-induzida [tese]. Bauru (SP): Universidade de São Paulo; 1999

2. Consolaro A. Reabsorções dentárias nas especialidades clínicas. 3ạ ed. Maringá: Dental Press; 2012

3. Consolaro A. Há vida no esmalte: metabolismo e circulação própria. Rev Dental Press Estét. 2004:1(1):123-7.

4. Francischone LA, Consolaro A. Clareação dentária externa: importância e tipos de proteção da junção amelocementária. Rev Clín Ortod Dental Press. 2005:4(5):88-98.
5. Francischone LA, Consolaro A. Morphology of the cement-enamel junction of primary teeth. J Dent Child. 2008;75(3):252-9

6. Esberard R, Esberard RR, Esberard RM, Consolaro A, Pameijer CH. Effect of bleaching on the cemento-enamel junction. Am J Dent. 2007:20(4):245-9

7. Neuvald L, Consolaro A. Cemento-enamel junction: microscopic analysis and external cervical resorption. J Endod. 2000;26(9):503-8

8. Pieroli DA. Avaliação do potencial carcinogênico dos agentes clareadores dentais [dissertação]. Bauru (SP): Universidade de São Paulo; 1997.

9. Consolaro A, Consolaro RB, Francischone L. Clareação dentária e o tratamento ortodôntico: esclarecimentos e orientações. Rev Clín Ortod Dental Press. 2013 ago-set;12(4):114-9. 